\title{
MENYIBAK PENYEBAB KETERLAMBATAN PENYELESAIAN LAPORAN KEUANGAN (Studi Kasus pada BKM Bunul Rejo Kota Malang)
}

\author{
Yuliati \\ Made Sudarma \\ Ari Kamayanti \\ Universitas Brawijaya \\ yuliatidjoenar@yahoo.co.id
}

\begin{abstract}
The background of this research is the high level of delays to complete the financial report which have an impact on the audit process delays and cycle BKM, cause a problem in acquiring fund's process from APBN and APBD. To explore the understanding of the actors from his experience directly involved in the financial reporting as well as to uncover the reality behind the making of financial reports, case studies are used as an approach to the paradigm intepretif. The results of the analysis from the main informant's experience, we find that the main problem of financial report's delay due to internal and external causes which coming from BKM itself. The three main parties were the source of the cause of the delay, namely the preparers of financial statements, the builder and the users of the financial statements.
\end{abstract}

Keywords: Delay, Financial Statement

\begin{abstract}
Abstrak
Penelitian ini dilatarbelakangi oleh suatu realitas terhadap sering terjadinya keterlambatan penyelesaian laporan keuangan yang membawa dampak terhadap tertundanya proses audit dan siklus BKM, sehingga berpengaruh terhadap keterlambatan perolehan dana yang bersumber dari APBN maupun APBD. Guna mengeksplorasi pemahaman para aktor dari pengalamannya terlibat langsung dalam pembuatan laporan keuangan serta untuk mengungkap realitas dibalik pembuatan laporan keuangan, studi kasus digunakan sebagai pendekatan dengan paradigma intepretif. Temuan yang didapat mengindikasikan bahwa penyebab keterlambatan penyelesaian laporan keuangan adalah masalah internal maupun eksternal yang ada di BKM. Tiga pihak utama yang menjadi sumber penyebab keterlambatan yaitu pembuat laporan keuangan, pembina dan pengguna.
\end{abstract}

Kata kunci: keterlambatan, laporan keuangan

\section{PENDAHULUAN}

Keterlambatan penyelesaian laporan keuangan seringkali menimbulkan masalah yang pengaruhnya begitu besar bagi suatu lembaga seperti tertundanya proses audit. Hal ini bisa berdampak lebih jauh dengan terhambatnya perolehan bantuan dana apabila hal tersebut dilakukan oleh suatu badan yang dikenal dengan Badan Keswadayaan Masyarakat (BKM).
Tertundanya perolehan dana yang sangat besar manfaatnya bagi masyarakat miskin, merupakan suatu hal yang sangat merugikan bagi penerima manfaat dana tersebut.

Penelitian terkait dengan ketepatan waktu dalam penyelesaian laporan keuangan baik di negara maju maupun di negara berkembang menarik sekali untuk dilakukan. Di Malaysia, penelitian serupa dilakukan oleh Tazik dan Mohamed (2014) memberikan beberapa 
Yuliati, Made Sudarma, Ari Kamayanti Jurnal InFestasi Vol.11, No.2, Desember 2015

bukti yang mendukung teori berbasis sumber daya, yang mengidentifikasi efektifitas sistem informasi akuntansi sebagai sumber daya yang dapat meningkatkan ketepatan waktu pelaporan keuangan perusahaan. Khusus di Indonesia, penelitian ini menjadi lebih menarik untuk dilakukan, karena keterlambatan penyelesaian laporan keuangan sering kali terjadi meskipun dalam lingkup tatanan yang paling rendah di masyarakat, sebagaimana dilakukan oleh BKM yang anggotanya terdiri dari masyarakat yang kurang mampu. Keterlambatan laporan keuangan yang dilakukan oleh BKM bisa dilihat dari hasil penilaian kinerja BKM yang dilakukan setiap bulan oleh fasilitator ekonomi, apabila laporan keuangan diselesaikan dan diinformasikan melalui lima tempat yang strategis yang bisa diketahui oleh masyarakat kurang dari tanggal lima setiap awal bulannya BKM dikatakan tepat waktu demikian sebaliknya.

BKM sebagai wadah aspirasi masyarakat yang dibentuk guna membantu pemerintah dalam memanfaatkan dana untuk disalurkan kepada masyarakat miskin baik untuk modal kerja berupa simpan pinjam dengan bunga yang sangat ringan juga penyaluran dana bagi pembangunan infrastruktur maupun kegiatan sosial. Setiap bulannya BKM membuat laporan keuangan sebagai cerminan bahwa program kerja telah dilaksanakan sesuai prosedur atau tidak, yang diinformasikan dalam bentuk laporan keuangan tersebut.

Tujuan penelitian yang ingin dicapai adalah untuk mengungkap realitas dan penyebab terjadinya keterlambatan dalam proses penyelesaian laporan keuangan di BKM Bunulrejo Malang dari perspektif aktor. Penelitian ini merupakan sebuah usaha awal guna mencoba melakukan penelitian mengenai keterlambatan penyelesaian laporan keuangan yang selama ini lebih banyak dilakukan dengan metode penelitian kuantitatif tetapi peneliti berupaya mempergunakan metode yang berbeda yaitu metode penelitian kualitatif yang selama ini masih jarang dijumpai.

Reformasi membawa dampak ke berbagai aktivitas kehidupan, tidak terkecuali terhadap pandangan masyarakat yang menuntut adanya perubahan diberbagai bidang. Perkembangan pola pikir masyarakat tidak terlepas dengan semakin maju dan maraknya penyampaian informasi melalui berbagai media, telah membuka wacana baru bahwa keterbukaan dalam segala hal sangat diharapkan oleh masyarakat pada saat ini. Penyelenggaraan segala aktivitas dalam kehidupan sehari-hari menuntut adanya suatu pertanggungjawaban dalam pencapaian tujuan yang diharapkan. Bentuk pertanggungjawaban ini lebih dikenal secara luas dengan istilah akuntabilitas. Akuntabilitas secara harfiah dalam bahasa Inggris biasa disebut dengan accountability, yang berarti "yang dapat dipertanggungjawabkan". Pengertian akuntabilitas disini lebih mengarah pada kewajiban dari individu atau penguasa untuk mempertanggungjawabkan pengelolaan sumber daya serta pelaksanaan segala kebijakan yang telah dipercayakan serta mampu menjelaskan bagaimana realisasi yang telah dijalankan selama ini.

Implementasi akuntabilitas di BKM bisa terwujud dengan baik, bila tanggungjawab kunci yang dimiliki oleh BKM untuk menjamin aset organisasi selalu digunakan untuk mencapai tujuan yang telah ditetapkan dengan menjamin catatan administrasi dan pembuatan laporan keuangan dilakukan dengan tepat dan benar. Penyelesaian laporan keuangan BKM dengan tidak mengalami keterlambatan juga merupakan bentuk diterapkannya akuntabilitas sebagai bentuk tanggungjawab BKM kepada masyarakat luas. Laporan yang disusun harus sesuai dengan ketentuan yang berlaku. BKM juga menjamin sistem dan prosedur 
Yuliati, Made Sudarma, Ari Kamayanti Jurnal InFestasi Vol.11, No.2, Desember 2015

keuangan yang ada dalam organisasi selalu ditaati, apabila ada ketidaksesuain akan dilaporkan secara transparan.

Laporan pertanggungjawaban BKM atas pengelolaan dana baik yang bersumber dari BLM maupun partisipasi masyarakat selama satu periode yang disampaikan melalui forum musyawarah tingkat kelurahan yang dikenal dengan Rembug Warga Tahunan (RWA), juga merupakan bentuk akuntabilitas BKM terhadap kinerja yang telah dijalankan selama satu tahun. Sebelum RWA dilakukan BKM harus melaksanakan proses audit independen untuk memberikan keyakinan secara independen atas akuntabilitas penggunaan dana oleh BKM/LKM dan pihak-pihak pelaksana kegiatan, termasuk kepatuhan terhadap peraturan PNPM yang berlaku, anggaran dasar BKM/LKM, pengendalian internal dan mendeteksi adanya kecurangan dan korupsi. Penerapan Akuntabilitas di BKM diharapkan mampu menjamin kinerja pelayanan BKM kepada masyarakat menjadi lebih baik dan tujuan untuk mencapai masyarakat yang lebih mandiri akan mudah diwujudkan.

\section{METODE}

Penelitian ini dilakukan dengan mengedepankan peran peneliti selama proses penelitian, untuk mengkaji secara lebih mendalam terhadap situasi yang sedang diteliti. Guna mengeksplorasi pemahaman para aktor yang terlibat dalam pembuatan laporan keuangan yang dilakukan oleh BKM, sesuai dengan tujuan penelitian diharapkan akan diperoleh pemahaman secara lebih jelas, mendalam dan terperinci dengan terungkapnya realitas yang terjadi terkait aspek-aspek yang menyebabkan keterlambatan dalam penyelesaian laporan keuangan. Peneliti bertindak sebagai instrumen utama, dimana hasil penelitian nantinya dituangkan ke dalam bentuk tulisan berdasarkan realita dan data yang ada di lapangan, sehingga akan diperoleh gambaran maupun hasil analisa yang lebih maksimal dan mendalam. Oleh karena itu penelitian ini dilakukan dengan menggunakan pendekatan kualitatif, yang diharapkan mampu menjawab permasalahan dan terwujudnya tujuan penelitian.

Pada penelitian ini, peneliti menggunakan paradigma interpretif guna mengungkap realitas sebagai konstruksi dari pengalaman dan kesadaran dalam proses penyelesaian laporan keuangan di BKM, sehingga nantinya diharapkan akan diperoleh pemahaman melalui intepretasi dari informan dalam memahami dan menjelaskan secara lebih mendalam tentang penyebab keterlambatan dalam penyelesaian laporan keuangan di BKM melalui pengalaman yang dimiliki. Penelitian kualitatif merupakan salah satu bentuk penelitian interpretif dimana di dalamnya para peneliti kualitatif membuat suatu interpretasi atas apa yang mereka lihat, dengar dan pahami (Creswell, 2013:262). Paradigma intepretif pada dasarnya memiliki karakteristik utama untuk memahami dan menjelaskan dunia sosial khususnya dalam sudut pandang orang-orang yang terlibat langsung dalam proses sosial tersebut (Burrel dan Morgan, 1979:227).

Peneliti dalam kegiatan penelitian ini memanfaatkan studi kasus sebagai riset desain dengan beberapa pertimbangan. Kasus yang diteliti adalah terkait keterlambatan penyelesaian laporan keuangan yang dialami oleh sebagian besar BKM di Kota Malang. Sebagai lembaga masyarakat yang diberi amanah untuk mengelola dana baik yang bersumber dari pemerintah pusat maupun daerah, laporan keuangan adalah salah satu bentuk pertanggungjawaban BKM dalam memanfaatkan dana untuk dilaporkan kembali baik kepada pemerintah maupun masyarakat. Dipilihnya BKM Bunulrejo sebagai situs penelitian dan ingin mengungkap kasus keterlambatan penyelesaian laporan keuangan di BKM tersebut dikarenakan dari 57 BKM, BKM Bunul lah yang dananya masih cukup 
Yuliati, Made Sudarma, Ari Kamayanti Jurnal InFestasi Vol.11, No.2, Desember 2015

besar digulirkan di masyarakat melalui program simpan pinjam, sedangkan di BKM lain hampir $45 \%$ sudah tidak aktif. Upaya yang dilakukan peneliti dengan penggalian informasi yang mendalam dari informan kunci melalui pengalaman yang dimiliki selama membuat laporan keuangan guna mengungkap realitas yang terjadi terhadap keterlambatan dalam menyelesaikan laporan keuangan. Studi kasus dinilai mampu untuk menghasilkan kajian yang mendalam sehingga permasalahan penelitian bisa terjawab dan tujuan penelitian dapat dicapai.

Untuk memperoleh data yang dibutuhkan dan sesuai dengan pokok permasalahan yang diteliti, peneliti menggunakan metode pengumpulan data yang saling melengkapi yaitu wawancara, dokumentasi dan observasi. Analisis data dalam penelitian ini lebih diarahkan pada suatu proses mencari dan menyusun secara sistematis data yang sudah diperoleh baik melalui proses wawancara, catatan dilapangan dan dokumentasi dengan cara mengorganisasikan data kedalam kategori, menjabarkan ke dalam unitunit, melakukan sintesa, menyusun ke dalam pola, memilih mana yang penting yang akan dipelajari kemudian membuat kesimpulan yang mudah difahami baik oleh diri sendiri maupun orang lain (Sugiyono, 2009:244).

\section{PEMBAHASAN}

Suasana sore yang diliputi hujan deras mengiringi langkah peneliti yang penuh semangat untuk segera bertemu dengan para personel BKM. Alangkah terkejutnyanya ketika mendapati pagar kantor masih terkunci rapat hanya spanduk selamat datang yang ditujukan untuk tim juri dari Propinsi Jawa Timur pada lomba bulan gotong royong menjadi saksi bisu menyambut kedatangan peneliti. Jam di tangan sudah menunjukkan pukul 16.45 WIB muncullah seorang wanita setengah baya dengan memakai payung terlihat tergopoh-gopoh membuka kunci pagar dan segera menyambut kedatangan peneliti yang hampir satu jam berteduh di depan kantor BKM, dengan penuh kehangatan dan keramahan beliau memeluk dan menanyakan kabar peneliti. Beliau adalah Ibu Hendah selaku UPK BKM Bunulrejo yang selalu datang lebih awal dan tekun menjalani rutinitas di BKM.

Kesibukan para personel BKM membuat tidak disiplinnya dalam jam kerja, seharusnya jam kerja BKM dimulai pada pukul 16.00 WIB -20.00 WIB. Akhir-akhir ini para personel BKM disibukkan dengan kegiatan di luar BKM, seperti Koordinator BKM yang tugas sehari-harinya adalah kepala sekolah SMP Shalahudin Malang. Pembicaraan semakin seru dan terus berlanjut, sebagaimana petikan wawancara yang disampaikan peneliti berikut ini:

Peneliti : "Padat ya Pak agenda panjenengan akhir-akhir ini?"

Abah : "Ya tahun 2015 ini penuh kunjungan yang sangat merepotkan bagi kepala sekolah, mulai ada pemeriksaan BPK terkait dana bos. Butuh suatu persiapan baik materi, laporan maupun teknis administrasi terkait kunjungan. Disamping itu juga acara rutin di sekolah mba mulai Unas, pelepasan kelulusan siswa dan sebentar lagi Isro' Mi'roj. Memang akhir-akhir ini kehadiran anggota BKM sering terlambat karena seperti pak Mariyanto juga ngajar di SMA, Pak Narto sibuk di developer ini Bu Antok (sapaan akrab Bu Hendah) juga menjabat kepala sekolah paud, jadi semua anggota disini rata-rata banyak dibutuhkan oleh masyarakat, belum lagi ada yang mendapat undangan selaku MC untuk hajatan."

Suasana BKM yang biasanya ramai dengan kehadiran para personel BKM, akhir-akhir ini terasa sepi hanya tiga orang yang rutin hadir, Ibu Hendah dan Pak Narto selaku UPK dan Mba Wiwin selaku sekretariat. Kondisi ini membawa dampak terhadap rutinitas penyelesaian 
Yuliati, Made Sudarma, Ari Kamayanti Jurnal InFestasi Vol.11, No.2, Desember 2015

laporan keuangan, dengan jam kerja yang semakin terbatas pencatatan laporan keuangan sering tertunda sampai dengan penyelesaian dalam bentuk laporan keuangan berupa neraca maupun laporan rugi laba menjadi terlambat

Perkembangan kegiatan pinjaman bergulir di BKM yang cukup pesat, ini berarti piutang yang mengendap di masyarakat juga semakin banyak pula. BKM dalam perhitungan kolektibilitas piutang, membagi kategori peminjam dalam 5 hal sesuai dengan ketepatan waktu pembayaran. Dikatakan piutang lancar apabila KSM tidak menunggak sama sekali, sedangkan piutang tidak lancar terbagi : terlambat 1 hari -3 bulan, terlambat 3 bulan lebih satu hari - 6 bulan, terlambat 6 bulan satu hari 9 bulan, dan kategori terakhir apabila terlambat diatas 9 bulan. Realitas yang terjadi pada perhitungan di kolektibilitas piutang ternyata tidak sama dengan total riil piutang yang ada di neraca. Selisih piutang yang terjadi berlarut-larut hingga saat ini belum ada solusinya disebabkan oleh banyak hal antara lain:

Pertama, perhitungan piutang yang mengendap di masyarakat yang biasa dikenal dengan RR (Repayment Rate) melalui kolektibilitas piutang dilakukan oleh petugas yang berbeda dengan petugas bagian yang memasukkan data ke neraca. Biasanya $\mathrm{Bu}$ Hendah yang bertugas membuat kolektibilitas piutang, sedangkan Pak Narto yang bertugas memasukkan data ke neraca.

Kedua, data piutang yang terjadi selisih sejak awal tidak segera dicarikan solusi untuk segera dibetulkan, sehingga rentang selisih total piutang lama kelamaan semakin besar antara piutang yang ada di kolektibilitas dengan yang ada di neraca, dimana seharusnya jumlahnya harus sepadan sebab kolektibilitas merupakan perhitungan riil piutang sedangkan neraca merupakan hasil akhir dari pencatatan.

Kekesalan petugas yang membuat laporan keuangan di BKM, disebabkan oleh sering terlambat penyelesaian laporannya hanya dikarenakan oleh selisih jumlah piutang. Kegundahan akan permasalahan yang sudah menumpuk menyebabkan UPK justru menjadi lebih malas untuk mengerjakan laporan keuangan. Jumlah KSM yang tertera di perhitungan kolektibiitas mencapai 134 KSM sehingga membutuhkan ketelitian yang sungguhsungguh sehingga hasil akhir dari perhitungan piutang bisa tepat. Tetapi karena sudah emosi dan kesal UPK semakin jenuh dan merasa pusing untuk terus mencoba memperbaiki perhitungan piutang.

Keterbatasan kemampuan sumber daya manusia dalam mempergunakan komputer juga menghambat penyelesaian laporan keuangan, sehingga apa yang seharusnya diatur dengan sistem untuk memudahkan UPK dalam membantu membuat laporan keuangan dengan sekali input mulai CUM (Catatan Uang Masuk) dan CUK (Catatan Uang Keluar) sudah nyambung (nge-link) untuk jadi laporan keuangan seperti Neraca dan Laba Rugi. Tetapi malah menghambat apabila UPK salah meletakkan posisi linknya sehingga hasilnya tidak nyambung dan membuat bingung UPK, sehingga UPK tetap mempertahankan proses manualnya untuk menghindari terjadinya kesalahan dalam pencatatan. Dengan proses yang kembali manual membuat penyelesaian laporan keuangan membutuhkan waktu yang lebih lama lagi dan seringkali terlambat.

Laporan hasil audit terakhir yang dimiliki oleh BKM adalah audit tahun 2012 yang dilaksanakan oleh Universitas Widia Gama. Tahun 2013 dilakukan oleh KAP Ghoni hanya draft audit yang sudah jadi itupun diberikan kepada BKM melalui fax. Audit tahun 2014 sampai saat ini belum selesai sedangkan untuk tahun 2015 baru dilaksanakan proses audit pada tanggal 5 Maret 2015.

Keluhan yang dirasakan oleh BKM terkait hasil audit adalah dalam hal penjelasan hasil audit terkadang mempergunakan bahasa yang sulit 
Yuliati, Made Sudarma, Ari Kamayanti Jurnal InFestasi Vol.11, No.2, Desember 2015

dimengerti oleh BKM, sehingga ketika BKM akan melakukan penyesuaian banyak mengalami kendala. Mbak Wiwin yang biasanya selalu tampil energik begitu berapi-api saat mengungkapkan kekesalannya dengan terlambatnya hasil audit yang diterima BKM, sebagaimana disampaikan oleh Mba Wiwin dalam petikan wawancara berikut ini:

"Terkait audit itu lho mba Yuli penjelasan bahasanya kadang sulit dimengerti kita mau mengikuti hasil audit untuk penyesuaian jadi sulit apalagi audit 2013 katanya tiga kali harus ganti bendera ternyata hasilnya juga wasalam."

Pembicaraan disambung oleh Pak Narto yang malam itu mengungkapkan kekecewaannya terhadap auditor dengan penuh semangat beliau menjelaskan sebagai berikut:

Pak Narto :"Sampai sekarang belum keluar hasil auditnya Mba, kalau itu nunggu piutangnya cocok kata Pak Imam Faskel gitu Mba."

Peneliti:"Menurut Konsultan bagaimana Pak melihat kondisi seperti ini tindak lanjutnya apa?'

Pak Narto :"Yang terakhir koordinir audit itu dilakukan oleh koordinator kota, maksud saya itu kan gini mba gimana kalo audit bisa mengambil kebijakan dari laporan yang dihasilkan dapat langsung dijadikan dasar untuk pijakan pembuatan laporan tahun berikutnya tidak berlarut-larut seperti sekarang sehingga kita mau menyelesaikan laporan tidak menunggununggu."

Keberadaan BKM Bunulrejo dalam melaksanakan kegiatannya sebagai lembaga yang berfungsi sebagai salah satu pilar pemberdayaan masyarakat di Bunulrejo, peran ini tidaklah maksimal bila tidak ditunjang dengan laporan keuangan yang rutin dibuat oleh BKM. Perwujudan amanah yang diberikan oleh masyarakat dalam mengelola dana bantuan dari pemerintah untuk dikembangkan melalui kegiatan pinjaman bergulir yang dimanfaatkan baik sebagai modal maupun penunjang usaha untuk meningkatkan ekonomi rumah tangga bagi warga Bunulrejo. Sudah sepatutnya pada saat kegiatan Rembug Warga Tahunan BKM menyampaikan hasil yang dicapai selama satu tahun berjalan dengan disertai bukti berupa laporan keuangan yang sudah diaudit oleh kantor akuntan publik yang ditunjuk.

Peran laporan keuangan menjadi sangat penting manakala dibuat tepat pada waktunya, sehingga informasi yang disampaikan lebih akurat dan keputusan yang diambil oleh pengguna laporan keuangan menjadi lebih relevan. Bagi UPK selaku pihak yang membuat laporan keuangan, memaknainya sebagai suatu yang penting untuk dibuat sebagaimana disampaikan oleh Ibu Hendah disela-sela kegiatannya mengungkapkan:

"Yo penting Mba laporan keuangan itu, karena kita memang diamanahi untuk mengelola keuangan di BKM, biar tidak ada yang negatif yang bawa uang itu takut dicurigai menggelapkan dan sebagainya."

Begitu pentingnya bagi UPK, mengingat manfaat laporan keuangan yang dibuat dirasakan sebagai bentuk pertanggungjawaban atas apa yang selama diamanahkan karena menyangkut keuangan, sehingga hal-hal yang ditakutkan dan dicurigai melakukan pelanggaran dengan menyalahgunakan dana yang digulirkan bisa ditepis. Hal ini senada dengan pendapat Pak Narto, sebagaimana disampaikan pada petikan wawancara berikut ini:

"Yang penting di sini ini tidak ada korupsi Mba, intinya itu saja maka nya kita bisa tetap eksis sampai dengan saat ini dikala BKM-BKM lain banyak yang gulung tikar." 
Yuliati, Made Sudarma, Ari Kamayanti Jurnal InFestasi Vol.11, No.2, Desember 2015

Realitas yang terjadi pergantian fasilitator bidang keuangan yang lebih dikenal dengan Faskel Ekonomi sering dilakukan dalam jangka waktu yang relatif cepat, sehingga pendampingan menjadi tidak maksimal. Sering bergantigantinya faskel menyebabkan UPK merasa proses adaptasi juga mengganggu kinerja mereka. Belum lagi pola pendampingan yang kurang sepenuh hati kerapkali dirasakan oleh UPK, faskel hanya datang sebulan sekali menagih laporan keuangan tanpa memperdulikan kendala yang dihadapi oleh UPK dalam pembuatan laporan. Aturan baru yang seringkali membingungkan UPK kerap dialami dikarenakan faskel tidak menjelaskan secara detail maksud dan tujuan dilakukan pembaharuan dalam proses pembuatan laporan keuangan. Hal ini sebagaimana dikutip dari wawancara dengan Bu Hendah sebagai berikut:

"Kalo saya ngerjakan RR itu tidak didampingi faskel mau tanya ke siapa saya bingung Mbak. Saya nggarap sampai mblenger komputer sampai kebheken data padahal cuma satu giga katanya masih salah-salah terus Mbak, saya jadi males buat RR."

Selama melakukan penelitian di BKM antara tanggal 15 April 2015 sampai 20 Juni 2015, peneliti menyaksikan langsung pergantian konsultan selaku pendamping BKM. Pada saat pertama kali kunjungan ke BKM, faskel yang mendampingi waktu itu adalah Pak Imam ternyata pada awal Juni 2015 Pak Imam dirolling ke Kecamatan Lowokwaru, sedangkan BKM Bunulrejo didampingi oleh Yanti selaku faskel baru. Secara tidak langsung pergantian faskel juga sangat mempengaruhi kinerja UPK, pembuatan laporan keuangan sering tertunda untuk sekedar melayani apa yang dibutuhkan oleh faskel.

BKM Bunulrejo pada saat ini mulai mengalami kejenuhan melakukan rutinitas terkait pemberian informasi melalui laporan keuangan yang dibuat. Bentuk transparansi yang ditunjukkan oleh BKM kurang mendapat tempat dihati pengguna laporan keuangan. Pihak Kelurahan Bunulrejo kurang memberi respon positif manakala BKM secara rutin tiap bulan memberikan laporan keuangan. Sebagaimana disampaikan oleh Mba Wiwin selaku sekretariat BKM

"Kadang mulai jenuh Mbak mengirim laporan keuangan ke kelurahan, kita yang membuat susah-susah eh sama pihak kelurahan cuma dimasukan slorokan tidak diarsip dengan baik, dan tanggapan mereka cuek setiap kali kita datang kesana."

Kenyataan inilah yang mendukung
UPK semakin tidak giat dalam
menyelesaikan laporan keuangan yang
dibuat tepat pada waktunya. Padahal
apabila ada kunjungan yang rutin
dilakukan oleh pemerintah daerah
maupun pusat baik melalui Bawas
ataupun BPKP, seringkali kunjungan
diawali ke instansi pemerintah dalam hal
ini kelurahan. Apabila data terkait
keuangan BKM diarsip dengan baik
mereka tidak akan kesulitan menjawab
pertanyaan seputar keuangan BKM
karena pada tupoksinya BKM
mempunyai Bajan kewajiban
memberikan laporan keuangan setiap
bulannya ke kelurahan.

\section{PENUTUP}

Penyebab keterlambatan dalam penyelesaian laporan keuangan yang ada di BKM Bunulrejo lebih banyak dipengaruhi oleh masalah internal maupun eksternal. Masalah internal yang menjadi penyebab keterlambatan adalah mulai kesibukan BKM maupun UPK diluar tugas utamanya menjadi pemicu terjadinya penundaan dalam menyelesaikan laporan keuangan. Sebagaimana perspektif yang dimiliki $\mathrm{H}$. Mashuri selaku koordinator BKM, beliau menjelaskan bahwa hampir seluruh BKM 
Yuliati, Made Sudarma, Ari Kamayanti Jurnal InFestasi Vol.11, No.2, Desember 2015

punya kesibukan di luar tugasnya selaku BKM.

Kurangnya kemampuan dalam mengoperasikan komputer seringkali menghambat dalam menyelesaikan laporan keuangan, sistem akuntansi yang diharapkan bisa membantu dalam memperlancar tugas UPK seringkali malah membuat bingung dan salah memasukan angka sehingga laporan keuangan yang dihasilkan menjadi tidak maksimal. Berikut perspektif Bapak Sunarto selaku UPK yang bertugas menginput data manual ke dalam komputer mengungkapkan kesulitannya dalam mengoperasikan komputer, kadang salah pencet rumusnya hilang laporan keuangan jadinya malah selisih.

Perspektif $\mathrm{Bu}$ Hendah atau yang lebih dikenal dengan panggilan $\mathrm{Bu}$ Antok, saya sering kesal dengan pembuatan RR (Repayment Rate) perhitungan piutang yang salah terus karena tidak didampingi faskel selaku pembina. Kesalahan dalam pencatatan piutang macet yang tidak diselesaikan dari dulu menghambat terselesainya laporan keuangan karena hasilnya tidak seimbang. Dampak dari semua masalah tersebut menyebabkan proses audit juga tertunda penyelesaiannya, sehingga siklus BKM yang seharusnya bisa diselesaikan tepat waktu menjadi terhambat.

Masalah eksternal yang menghalangi terselesainya laporan keuangan tepat pada waktunya adalah sering berganti-gantinya konsultan selaku pembina pembuatan laporan keuangan. Proses adaptasi dari faskel baru malah mengganggu kinerja UPK dalam menyelesaikan laporan keuangan. Pengarahan dan pembinaan yang berbeda-beda juga mempengaruhi UPK yang kadang dibuat tidak memahami apa yang disampaikan oleh konsultan. Cara pendekatan yang berbeda-beda serta kesungguhan dalam mengabdikan diri sebagai fasilitator juga sangat mempengaruhi kinerja UPK, termasuk aturan baru yang dibawa konsultan kadang malah membuat UPK bingung untuk mengerjakan khususnya terkait tentang laporan keuangan.

Laporan yang dihasilkan oleh BKM, seringkali kurang mendapat respon positif dari pengguna dalam hal ini pihak kelurahan maupun BKBPM selaku instansi yang menaungi BKM. Sebagaimana persepektif Mbak Wiwin selaku Sekretariat, yang merasa diabaikan manakala mengirim laporan keuangan ke kelurahan sebagai bentuk tanggungjawab BKM untuk mewujudkan transparansi dana yang selama ini dikelola oleh BKM. Laporan yang dikirim BKM setiap bulan seringkali tidak diarsip dengan baik, padahal hampir setiap tahun pemeriksaan baik dari daerah misalnya oleh BAWAS Kota Malang maupun dari Propinsi Jawa Timur oleh BPKP seringkali kunjungan awal tidak langsung ke BKM tetapi ke kelurahan atau ke BKBPM terlebih dahulu.

Penelitian yang dilakukan dalam rentang waktu kurang lebih hanya 2 bulan ini, peneliti merasa kurang mendalam. Banyak hal yang masih bisa digali guna mengeksplor secara lebih luas dan mendalam terkait apa saja yang menyebabkan keterlambatan dalam penyelesaian laporan keuangan di BKM, mengingat hampir 75\% BKM yang ada di Kota Malang ini seringkali mengalami keterlambatan.

Semoga keterbatasan ini menjadi pemicu peneliti berikutnya untuk lebih merasa tertantang mengadakan penelitian dengan pendekatan kualitatif yang masih jarang dilakukan menyangkut tentang keterlambatan dalam penyelesaian laporan keuangan yang ada di BKM. Selama ini penelitian tentang keterlambatan penyelesaian laporan keuangan lebih banyak menggunakan pendekatan kuantitatif dengan mengambil lokasi penelitian di perusahaan-perusahaan besar yang terdaftar di bursa efek. Peneliti juga berharap semoga peneliti berikutnya bisa membahas lebih dalam terkait tentang aturan atau Standard Operating Procedur (SOP) konsultan mengenai bentuk laporan keuangan agar lebih 
Yuliati, Made Sudarma, Ari Kamayanti Jurnal InFestasi Vol.11, No.2, Desember 2015

disederhanakan lagi, sehingga memudahkan BKM dalam menyusun dan menyelesaikan laporan keuangan lebih tepat waktu. Demikian juga masalah perlu tidaknya dilakukan audit eksternal bagi lembaga seperti BKM.

\section{DAFTAR PUSTAKA}

Bastian, Indra, 2009, Akuntansi Sektor Publik di Indonesia, Yogyakarta, BPFE.

Belkaoui, Ahmed Riahi, 2001, Accounting Theory, Edisi 5, Jakarta, Salemba Empat.

Burrel, Gibson \& Morgan, 1979. Sociological Paradigms and Organizational Analysis: Elements of the Sociology of Corporate Life. London: Heineman.

Creswell, John W. 2007, Qualitative Inquiry \& Research Design, Sage Publications, New Delhi.

Creswell, John W. 2013 Research Design Pendekatan Kualitatif, Kuantitatif, dan Mixed, Yogyakarta, Pustaka Pelajar. , Instruksi Presiden No.1 Tahun 2010 Tentang Penyusunan Rencana Integrasi Program Pemberdayaan Masyarakat. , Instruksi Presiden No.3 Tahun 2010 Tentang Program Pembangunan Yang Berkeadilan.

Hendrawaty, Rina, 2014, Akuntabilitas Masjid, Tesis, Universitas Brawijaya, Malang

Laswad, Fauwzi, 2005, Determinants of Voluntary Internet Financial Reporting by Local Government Authorities, Journal of Accounting and Public Policy, Vol. 24, No. 2, p.101-121.

Mardiasmo, 2009, Akuntansi Sektor Publik, Yogyakarta, CV. Andi Offset.

Moleong, 2013, Metodologi Penelitian Kualitatif, Bandung, Penerbit PT Remaja Rosdakarya Bandung.

Nordiawan, Deddi, 2006, Akuntansi Sektor Publik, Penerbit Salemba Empat.
Oladipupo, 2010, Relative Contributions of Audit and Management Delays in Corporate Financial Reporting, Empirical Evidence from Nigeria, International Journal of Business and Social Science, Vol 4, No.10, p.109-203.

Payne, Jeff L dan Jensen, Kevan L, 2002, An Examinination of Municipal Audit Delay, Journal of Accounting and Public Policy, Vol.21, No.1, p.129.

, Peraturan Presiden No.15 Tahun 2010 Tentang Percepatan Penanggulangan Kemiskinan.

Presidensby.info, 2007, Presiden Resmikan Peluncuran PNPM, http://www.kemendesa.go.id, Mei 2007.

Rachmad, Saleh, 2004, Studi Empiris Ketepatan Waktu Pelaporan Keuangan Perusahaan Manufaktur di Bursa Efek Jakarta, Tesis, Universitas Diponegoro Semarang.

Rudianto, 2008, Pengantar Akuntansi, Konsep dan Tehnik Penyusunan Laporan Keuangan, Penerbit Erlangga, Jakarta.

Sari, Dewi Ratna, 2012, Faktor-Faktor yang Memperngaruhi Keterlambatan Penyampaian Laporan Keuangan Perusahaan Manufaktur yang Terdaftar di Bursa Efek Indonesia Periode 2008-2010, Tesis, Universitas Negeri Semarang.

Standar Akuntansi Keuangan, 2009, PSAK No.1, Penerbit Salemba Empat, Jakarta.

Sugiyono, 2009, Metodologi Penelitian Kuantitatif Kualitatif dan $R \& D$, Bandung, Alfabeta.

Syafaat, Muhammad, 2013, FaktorFaktor yang Mempengaruhi Ketepatan Waktu Penyampaian Laporan Keuangan, Tesis, Universitas Brawijaya, Malang.

Tadesse, Solomon, 2006, The Economic Value of Regulated Disclosure Evidence from the Banking, Journal of Accounting and Public Policy, Vol. 25, No.1, p.1-29. 
Yuliati, Made Sudarma, Ari Kamayanti Jurnal InFestasi Vol.11, No.2, Desember 2015

Tazik, Hassan dan Mohammed, Zakiah Muhammadun, 2014, Accounting Information System Effectiveness, Foreign Ownership and Timeliness of Corporate Financial Report, Proceeding of 5 th Asia-Pasific Business Research Conference.

, Undang-Undang No. 17 tahun 2003 Tentang Keuangan Negara.

Undang-Undang No. 1 tahun 2004 Tentang Perbendaharaan Negara.

, Undang-Undang No. 15 tahun 2004 Tentang Pemeriksaan dan Tanggungjawab Keuangan Negara. , Undang-Undang No. 32 tahun 2004 Tentang Pemerintah Daerah.

Yuwono, Budi, 2010, Pedoman Pelaksanaan PNPM Mandiri Perkotaan, Kementerian Pekerjaan Umum, Jakarta. 
Yuliati, Made Sudarma, Ari Kamayanti Jurnal InFestasi Vol.11, No.2, Desember 2015 